\title{
Knockdown of STAT3 expression by RNAi induces apoptosis in astrocytoma cells
}

\author{
Liza Konnikova, Maciej Kotecki, Mathew M Kruger and Brent H Cochran*
}

Address: Department of Physiology, Tufts University School of Medicine 136 Harrison Ave., Boston, Massachusetts, 02111, USA

Email: Liza Konnikova - liza.konnikova@tufts.edu; Maciej Kotecki - maciej.kotecki@tufts.edu; Mathew M Kruger - matt@cochranlab.org; Brent H Cochran* - cochran@cochranlab.org

* Corresponding author

Published: 17 September 2003

BMC Cancer 2003, 3:23
Received: 14 July 2003

Accepted: 17 September 2003

This article is available from: http://www.biomedcentral.com/147I-2407/3/23

(C) 2003 Konnikova et al; licensee BioMed Central Ltd. This is an Open Access article: verbatim copying and redistribution of this article are permitted in all media for any purpose, provided this notice is preserved along with the article's original URL.

\begin{abstract}
Background: Astrocytomas are the most common type of primary central nervous system tumors. They are frequently associated with genetic mutations that deregulate cell cycle and render these tumors resistant to apoptosis. STAT3, signal transducer and activator of transcription 3 , participates in several human cancers by inducing cell proliferation and inhibiting apoptosis and is frequently activated in astrocytomas.
\end{abstract}

Methods: RNA interference was used to knockdown STAT3 expression in human astrocytes and astrocytoma cell lines. The effect of STAT3 knockdown on apoptosis, cell proliferation, and gene expression was then assessed by standard methods.

Results: We have found that STAT3 is constitutively activated in several human astrocytoma cell lines. Knockdown of STAT3 expression by siRNA induces morphologic and biochemical changes consistent with apoptosis in several astrocytoma cell lines, but not in primary human astrocytes. Moreover, STAT3 is required for the expression of the antiapoptotic genes survivin and $\mathrm{Bcl}-\mathrm{xL}$ in the AI72 glioblastoma cell line.

Conclusion: These results show that STAT3 is required for the survival of some astrocytomas. These studies suggest STAT3 siRNA could be a useful therapeutic agent for the treatment of astrocytomas.

\section{Background}

Astrocytomas are the most common type of primary tumors of the central nervous system. These tumors arise from either astrocytes or their progenitor cells [1] and represent the second leading cause of cancer related deaths in children and in young adults [1-5]. It is also the second fastest growing cause of cancer deaths among those over 65, and unlike lung cancer (first) and melanoma (third), no behavioral changes have been shown to reduce risk [6].
Astrocytomas are divided into four grades based on the malignancy of the tumor. Glioblastoma multiforme (GBM), grade IV, is the most common type with the worst prognosis [1-5]. Average post-operative survival after tumor resection is less than two years [1-5]. In young adults, grade IV astrocytomas usually progress from lower grade astrocytomas, while in older patients it frequently arises de novo [1-4]. Progressive astrocytomas are frequently associated with loss of function mutations in p53, $\mathrm{Rb}$ and Ink4a/p16 genes as well as amplifications of PDGFR, MDM2 and Cdk4 genes [5,7-13]. These 
mutations cause a deregulation of cell cycle and render these tumors resistant to apoptosis.

STATs, signal transducers and activator of transcription, are a family of transcription factors that transmit signals from cell surface receptors directly to the nucleus [14]. Activation of all the STAT proteins is caused by phosphorylation of a single tyrosine residue that leads to dimerization via an intermolecular SH2 phosphotyrosine interaction [15-18]. The dimerized STATs then translocate to the nucleus where they regulate gene expression by binding directly to high affinity DNA binding sites or by associating with other transcription factors [19-24]. They play a critical role in mediating cytokine and growth factor signaling involved in cell growth, differentiation and survival [25-28]. Among the seven members of mammalian STAT family, STAT3 has been most strongly implicated in oncogenesis [29]. STAT3 is ubiquitously expressed in mammalian cells and is activated by cytokines such as IL6 family members as well as growth factors such as EGF and PDGF [30]. Transient STAT3 activation is required for astrocytic differentiation [31]. However, the role of STAT3 signaling in adult astrocytes is unclear.

Although spontaneous mutations in the STAT3 gene have not been associated with tumorigenesis, constitutively activated STAT3 is found in a wide variety of human tumors including multiple myelomas, breast, ovarian, prostate, and head and neck tumors [31-37]. There is substantial evidence to implicate STAT3 activation in tumor progression. A number of studies have demonstrated that the transformation process induced by diverse oncogenic protein tyrosine kinases is dependent on STAT3 activation [37-39]. Inhibition of STAT3 signaling in a number of tumor cell lines with either small molecular inhibitors to block protein tyrosine kinases (PTKs) or with dominant negative/antisense STAT3 causes a decrease in cell viability and subsequent apoptosis $[31,34,40]$. Elevated STAT3 activity has been shown to render cells resistant to apoptosis by inducing anti-apoptotic genes such as $\mathrm{Bcl} 2$, Bcl$\mathrm{xL}$, and Mcl-1[37]. Recently it has been shown that STAT3 is constitutively activated in astrocytomas [41]. Here we show that knockdown of STAT3 expression by siRNA reduces levels of survivin and $\mathrm{Bcl}-\mathrm{xL}$ expression and triggers apoptosis in astrocytoma cells.

\section{Methods}

\section{Cell Lines and Culture Conditions}

The human astrocytoma cell lines A172 and T98G were obtained from the American Type Culture Collection (Rockville, MD). The U251-MG cell line was graciously donated by Dr. George Perides (Tufts-NEMC). These cell lines were derived from grade IV astrocytomas - glioblastoma multiforme (GBM). Normal human astrocytes (NHA) were obtained from ScienCell (San Diego, CA).
A172 and U251-MG cells were cultured in DMEM (ATCC, Rockville, MD) supplemented with $10 \%$ FCS. T98G was cultured in MEM (ATCC, Rockville, MD) supplemented with $10 \%$ FCS. Normal human astrocytes (NHA) were cultured in astrocyte medium (ScienCell, San Diego, MD).

\section{STAT3 siRNA and siRNA transfections}

We designed a double stranded siRNA oligonucleotide against STAT3 (5'-AAC AUC UGC CUA GAU CGG CUA dTdT-3'; 3'-dTdT GUA GAC GGA UCU AGC CGA U-5') and had it synthesized by Dharmacon Research, Inc (Lafayette, CO). Oligofectamine (Invitrogen, Carlsbad, $\mathrm{CA}$ ) was used as the transfection reagent following manufacturer's directions using 200-600 nmol of siRNA per 10 $\mathrm{cm}$ dish. Cells were incubated for $24 \mathrm{hrs}$ in Opti-MEM, at which point appropriate media for the cells supplemented with 30\% FCS was added. The cells were then incubated for the amount of time indicated in the Figure Legends.

\section{Immunoblotting}

For Western blot analysis, cells were harvested and lysed with RIPA buffer $(0.15 \mathrm{M} \mathrm{NaCl}, 1 \% \mathrm{NP} 40,0.01 \mathrm{M}$ desoxycholate, $0.1 \%$ SDS, $0.05 \mathrm{M}$ Tris- $\mathrm{HCl} \mathrm{pH} 8.0,1 \mathrm{mM}$ sodium orthovanadate, $1 \mathrm{mM}$ phenylmethylsulfonyl fluoride, and $10 \mu \mathrm{g} / \mathrm{ml}$ each of aprotinin, pepstatin, and leupeptin). For STAT3 analysis, protein samples were electrophoresed on a $10 \%$ SDS-PAGE gels for $90 \mathrm{~min}$. at $150 \mathrm{mV}$ and transferred onto Immobilon membranes (Millipore, Bedford, MA) for $60 \mathrm{~min}$ at $100 \mathrm{mV}$ in $10 \%$ methanol transfer buffer. For caspase- 3 analysis the protein samples were separated on a 15\% SDS-PAGE and transferred onto Immobilon membranes (Millipore, Bedford, MA) at $20 \mathrm{mV}$ for $20 \mathrm{~min}$ and $80 \mathrm{mV}$ for $2 \mathrm{hrs}$ in $20 \%$ methanol transfer buffer. The membranes were then probed with each antibody as indicated. Immunoreactive proteins were visualized using an enhanced chemiluminescence detection system (Amersham Pharmacia Biotech). Anti-phospho-STAT3, anti-STAT3, anti-cleaved Caspase 3, anti-Bcl-xL and anti 42-44 MAP kinase were obtained from Cell Signaling (Beverly, MA). Anti- $\beta$-actin antibody was obtained from Sigma (St. Luis, MO).

\section{Cell number assay}

For cell proliferation assays, cells were incubated for 72 hrs in 96-well plates in quadruplicates. Viable cell number was determined by using MTS assay according to the manufacturer's instructions (CellTiter 96 AQ Non-radioactive proliferation kit, Son Luis, CA). The absorbance was measured at $490 \mathrm{~nm}$ with a 96-well plate reader.

\section{FACS analysis}

Cells were treated with siRNA as described above. After 96 hours, cells were isolated and stained with annexin VEGFP (BD Biosciences Clontech, Palo Alto, CA). Cells were analyzed using FACS for fluorescence of annexin $\mathrm{V}$ 


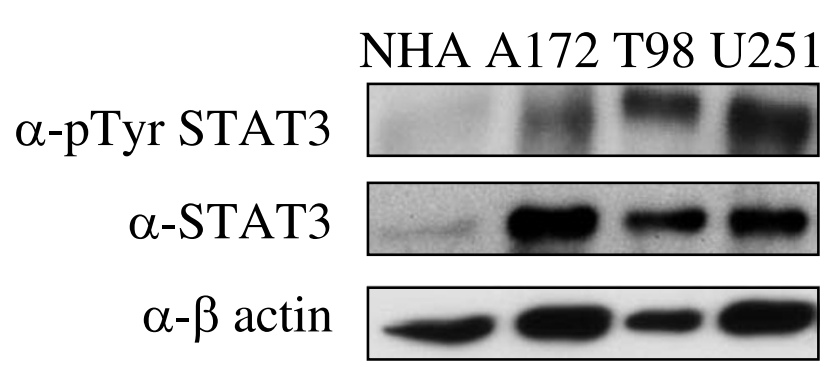

Figure I

STAT3 is expressed and active in GBM cell lines. The indicated cell lines were lysed in RIPA buffer after serum starvation for $24 \mathrm{hrs}$. Cell lysates were subjected to electrophoresis on an SDS PAGE gel and processed for Western blotting with anti-phospho-Tyr-STAT3, anti-STAT3, or anti$\beta$-actin antibodies. NHA are primary human astrocytes. All other cell lines are grade IV astrocytoma (GBM).

positive cells. The fraction of annexin $\mathrm{V}$ positive cells in the siRNA treated population was determined using the super-enhanced DMax method of WinList software (Verity Software House, Topsham, ME).

\section{Northern blot analysis}

The A172 cell line was treated with STAT3 siRNA as described previously and RNA purified with TRIzol (Invitrogen, Carlsbad, CA). $10 \mu \mathrm{g}$ of each RNA sample was loaded per well. After transferring onto a nylon membrane (Ambion, Austin, TX), it was probed with a survivin probe (Resgen) or p21 (gift of Sam Lee) labeled with ${ }^{32} \mathrm{P}$. Hybridizations were performed with Express Hyb (BD Biosciences Clontech, Palo Alto, CA) and washed following the manufacturers protocol. Blots were exposed to Kodak MS film overnight and developed. Blots were then quantitated using a Molecular Dynamics phosphorimager.

\section{Results}

STAT3 is constitutively activated in astrocytoma cell lines To determine whether STAT3 is expressed and constitutively activated in astrocytoma cell lines, we compared the level of STAT3 expression and tyrosine 705 STAT3 phosphorylation in normal human astrocytes (NHA) to that of three astrocytoma cell lines. Western Blot analysis with anti-STAT3 and anti-phosphotyrosine STAT3 antibodies revealed that STAT3 was overexpressed and overactivated in astrocytoma cells as compared to primary astrocytes (Figure 1). Reprobing the blot with anti- $\beta$-actin shows that variability in protein loading could not account for the observed differences in STAT3 expression.

\section{STAT3 RNAi specifically reduces STAT3 expression in astrocytoma cell lines}

Recent studies show that constitutive activation of STAT3 in variety of tumors directly contributes to their oncogenic potential by inducing proliferation and inhibiting apoptosis $[40,41]$. Thus, we sought to determine the effect of inhibiting STAT3 expression in astrocytoma cells.

To inhibit STAT3 expression in astrocytoma cells, we used the RNAi method adapted for mammalian cell culture by Elbashir et al [42]. A number of 21 bp double stranded RNAs to human STAT3 were synthesized and tested for their ability to knockdown STAT3 expression in astrocytomas. Transfection of cells with one of these STAT3 siRNAs (Figure 2a) resulted in a highly significant and reproducible decrease in STAT3 expression levels as judged by Western Blotting (Figure 2b). The degree of knockdown achieved ranged from 75-95\% depending upon the experiment and cell line used. STAT3 siRNA inhibited STAT3 expression in normal human astrocytes (NHA) as well as in astrocytoma cell lines (Figure 2b). Mock transfection with oligofectamine or with an siRNA to the green fluorescent protein (GFP) failed to reduce STAT3 expression. The effect of STAT3 siRNA was specific in that it failed to knock down expression of the unrelated proteins $\beta$-actin or Map Kinase. STAT3 knockdown by siRNA was found to be time dependent with the maximum effect achieved at 48-72 hrs of siRNA treatment (Figure 2c). This siRNA is human specific and does not efficiently knockdown expression of murine STAT3 (Data not shown).

\section{STAT3 RNAi induces morphology changes and decreases viability in astrocytoma cell lines}

We noted that upon STAT3 siRNA treatment of some of the astrocytoma lines that cultures were less confluent and some cells became smaller and rounder than control oligofectamine treated cells (Figure 3a). Consistent with this, there were fewer cells in both A172 and U251-MG cultures treated with STAT3 siRNA as compared to control oligofectamine treated cultures 72 hours post transfection (Figure 3b). Transfecting A172 cells a second time with STAT3 siRNA 48 hours after the initial transfection resulted in an even greater reduction in cell number (>90\% in A172 and 65\% in U251) as compared to oligofectamine controls (data not shown). Viability of normal human astrocytes (NHA) was not significantly affected by STAT3 siRNAi treatment. Another astrocytoma cell line, T98G, was only slightly affected by reductions in STAT3 expression (Figure 3b). Thus, not all astrocytoma cell lines 
A. Synthetic siRNA against STAT3

5'-CAU CUG CCU AGA UCG GCU AdTdT-3' 3'-dTdT GUA GAC GGA UCU AGC CGA U- 5'

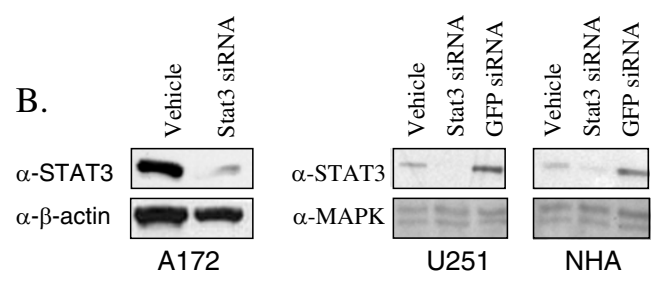

C.

$$
\alpha \text {-STAT3 } \quad \text { Oh } 6 \mathrm{~h} \quad 1 \mathrm{~d} \quad 3 \mathrm{~d}
$$

Figure 2

Knockdown of STAT3 by siRNA in primary human astrocytes and astrocytoma cells. $A$. Sequences of the synthetic siRNA duplex designed against human STAT3. B. The astrocytoma cell lines AI72 and U25I and normal human astrocytes (NHA) cultured in $10 \mathrm{~cm}$ plates were transfected with $600 \mathrm{nmol}$ STAT3 siRNA and after 72 hours processed for Western blotting with anti-STAT3 antibodies. The blots were subsequently stripped and reprobed with anti- $\beta$-actin or anti-Map Kinase antibodies as controls. C. Al72 cells were transfected with 600 nmol STAT3 siRNA for the times indicated and processed for Western blotting with anti-STAT3 antibodies.

are equally responsive to STAT3 knockdown. The decrease in cell number caused by STAT3 siRNA treatment of astrocytoma cells implies that STAT3 participates in cell cycle progression, cell survival, or both. Staining A172 cells for DNA content after STAT3 siRNA treatment showed an increased proportion of cells in early $S$ phase (data not shown). This could be due to an $S$ phase cell cycle block or to preferential apoptosis of these cells in late S and G2/ M.

\section{STAT3 RNAi induces apoptosis in astrocytoma cells}

The cell number decreases observed in conjunction with the morphological observations suggested that astrocytoma cells treated with STAT3 siRNA undergo apoptosis. To confirm that these cells undergo apoptosis in response to STAT3 knockdown, we examined three other indicators of apoptosis in the A172 cell line. First, cultures of astrocytoma cells were stained Hoechst 33258 dye and scored for apoptotic nuclei[43]. A significantly higher percentage of apoptotic nuclei were observed in STAT3 siRNA treated cells than in GFP siRNA or oligofectamine treated cells (Figure 4a). Consistent with this observation, Western blot analysis of astrocytoma cell extracts showed that there is increased cleavage of caspase 3 in STAT3 siRNA treated cells (Figure 4b). Finally, annexin V staining of control and STAT3 siRNA treated cells followed by fluorescence activated cell sorting analysis indicated a $77 \%$ increase in the fraction of annexin $\mathrm{V}$ positive cells, further confirming that these cells are undergoing apoptosis (Figure 4c)[44]. Together these data indicate that STAT3 regulates an anti-apoptotic program in astrocytomas and that inactivation of STAT3 leads to a rapid induction of apoptosis.

\section{Knockdown of STAT3 expression down regulates survival genes}

Recent data indicate that constitutive activation of STAT3 induces the expression of a number of anti-apoptotic genes including Bcl-xL, a member of the Bcl-2-family of anti-apoptotic genes [32,45], and survivin, a member of the IAP, inhibitors of apoptotic proteins family [46]. Moreover, both of these genes are expressed in astrocytomas $[47,48]$. In order to determine whether these two genes might be involved in the STAT3 mediated apoptotic block in astrocytoma, Northern and Western blot analyses were performed to examine the expression levels of these two genes. Northern blot analysis showed that STAT3 siRNA reduced expression of survivin by $75 \%$ (Figure $5 \mathrm{a}$ ). Western blot analysis showed that Bcl-xL protein levels were drastically reduced upon treatment with STAT3 siRNA. Thus, these data show that STAT3 regulates the expression of at least two distinct antiapoptotic genes in the A172 cell line.

\section{Discussion}

STAT3 is activated by a number of cytokines and growth factors and has diverse functions during embryogenesis and early development [25-28]. Due to the transient nature of cytokine and growth factor signaling and the presence of proteins such as SOCS, suppressor of cytokine signaling, and PIAS, protein inhibitor of activated $\underline{\text { STAT, }}$ that inhibit of STAT3 signaling, STAT3 activation under normal physiological conditions is transient, lasting anywhere from several minutes to several hours [49]. However, during tumorigenesis there is often constitutive activation of PTKs due to activating mutations or aberrant growth factor or cytokine signaling. Constitutive PTK signaling results in constitutive activation of STAT3 [38]. It is therefore not surprising that recent studies show that there is persistent activation of STAT3 in a number of human cancers including multiple myelomas, breast, ovarian and prostate carcinomas and head and neck tumors [32-37].

The initial evidence that STAT3 signaling is critical to tumorigenesis came from the observation that activation of STAT3 is necessary for $\mathrm{v}$-src induced transformation of NIH3T3 cells [38,39]. Subsequent studies have shown that STAT3 activation is crucial to cellular transformation induced by a number of viral oncogenes [37]. Inhibition 
A.
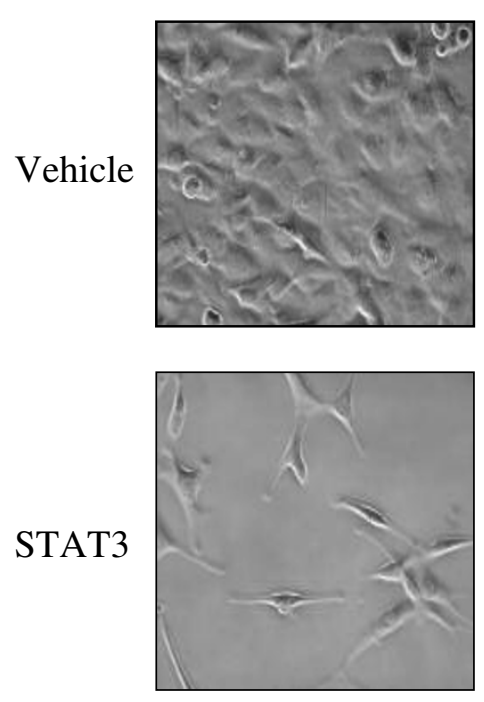

B.

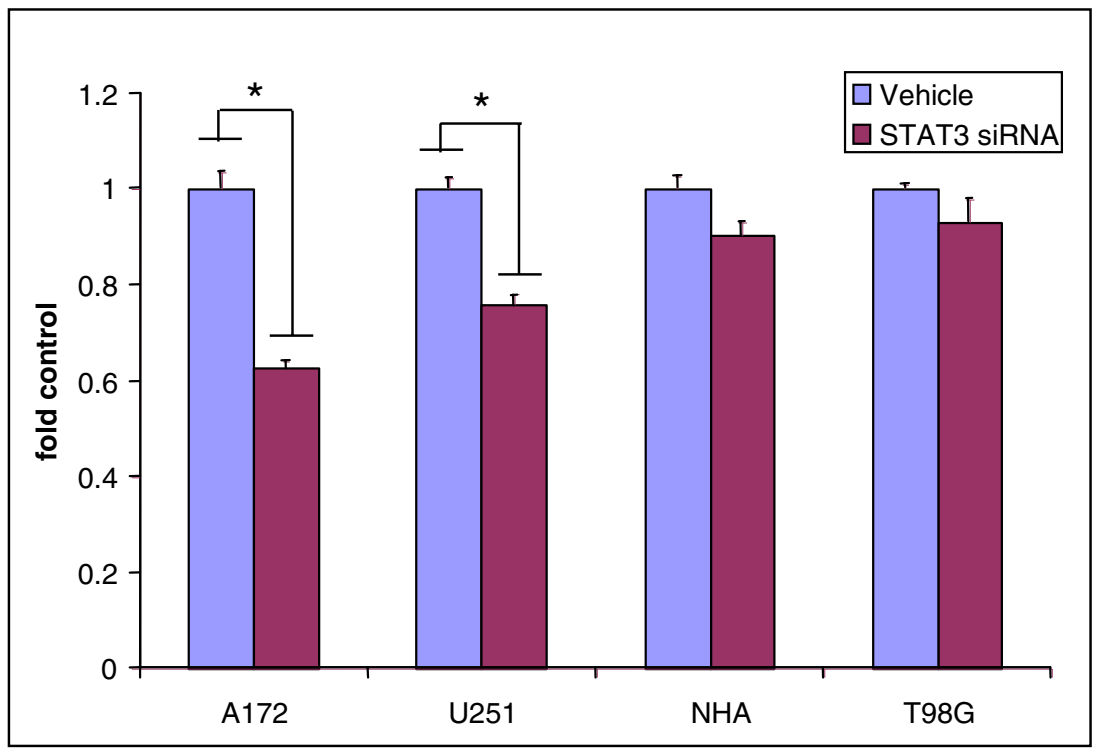

\section{Figure 3}

STAT3 siRNA causes a decrease in cell number in glioblastoma cell lines. A. AI72 cells were transfected with a STAT3 siRNA (bottom panel) or a control siRNA (top panel). Cells were photographed 72 hours post transfection at 200x magnification. B. A I72, U25I, T98G, and NHA cells were transfected with STAT3 siRNA or mock transfected with oligofectamine (vehicle). Viable cell numbers were determined by MTS assay 72 hours after transfection. $(*)$ indicates a $P$ value $<0.001$.

of STAT3 signaling with either dominant negative or antisense oligonucleotides against STAT3 suppresses the transformation process in some tumors [34,50]. Overexpression of a constitutively active mutant of STAT3 transforms 3T3 cells in culture [51]. Finally, recent studies have shown that treatment of tumor cells with inhibitors of STAT signaling results in decreased cell viability and induces apoptosis $[40,41]$. Together these findings demonstrate that STAT3 signaling plays a critical role in both the transformation process and tumor progression in some types of cancer.

Ourselves and others have found STAT3 is constitutively activated in astrocytomas and astrocytoma cell lines $[41,52]$. This is consistent with the fact that human astro- cytomas are often characterized by an amplification of either growth factor genes, such as PDGF, growth factor receptor genes, such as the EGF receptor, or cytokines such as IL- 6 that can lead to constitutive activation of STAT3 $[53,54]$. Not surprisingly, there was constitutive STAT3 activation in all astrocytoma cell lines tested. In contrast, NHA showed relatively little STAT3 expression and activation.

In order to determine the role of STAT3 in astrocytomas directly, we have used RNAi to specifically knock down the expression of STAT3 in several human astrocytomas. Treatment of astrocytoma cell lines with STAT3 siRNA resulted in morphologic and biochemical changes indicative of apoptosis. These results are consistent with 
A.
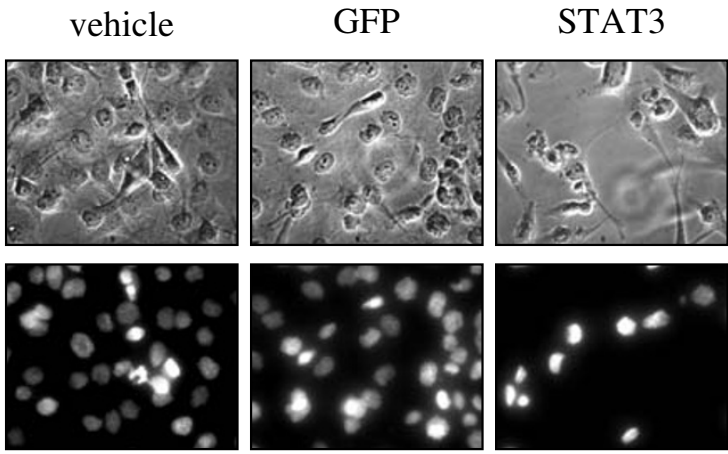

\begin{tabular}{|ccc|}
\hline & \% apoptotic nuclei & p value \\
\hline vehicle & $14+/-3$ & \\
GFP siRNA & $20+/-8$ & 0.18 \\
STAT3 siRNA & $60+/-7$ & $<.01$ \\
\hline
\end{tabular}

B.

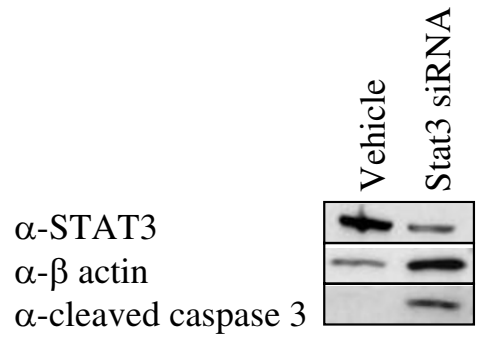

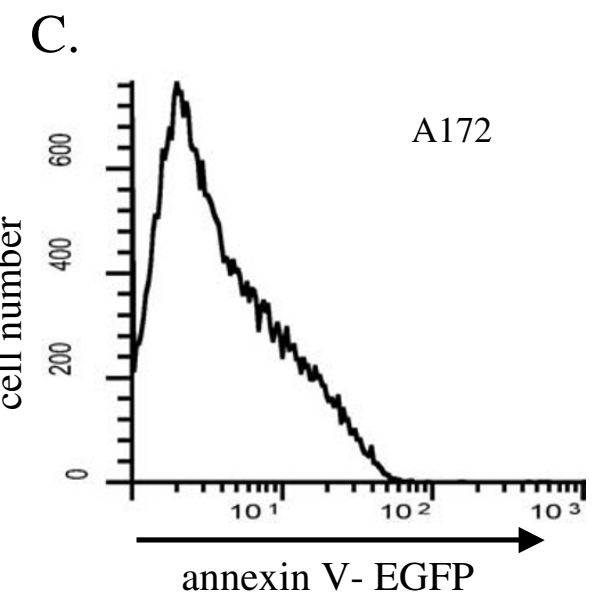

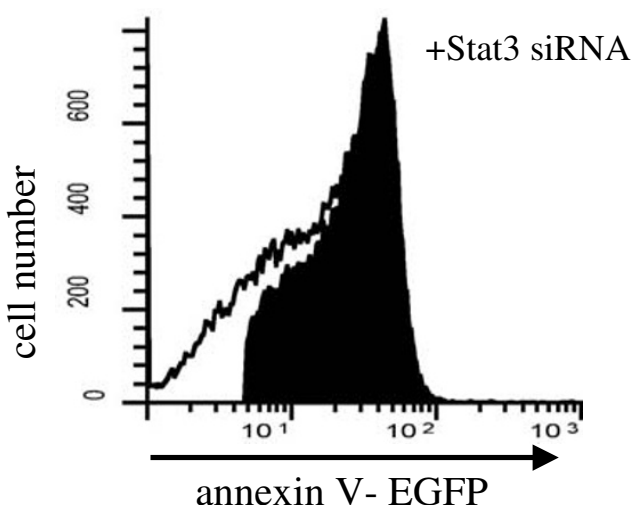

\section{Figure 4}

Induction of apoptosis in human astrocytomas by STAT3 RNAi. A. AI72 cells were transfected with STAT3, GFP siRNAs, or mock transfected with oligofectamine (vehicle). After $72 \mathrm{hrs}$, cells were fixed in $4 \%$ paraformaldehyde and stained with $25 \mu \mathrm{g} / \mathrm{ml}$ Hoechst 33258 dye to visualize apoptotic nuclei. The percentage of apoptotic cells (small bright nucleus) was determined for each of the treatments by counting five visual fields and at least 100 cells. B. AI 72 cells were transfected with STAT3 siRNA or mock transfected with oligofectamine. Western blotting was performed 72 hrs post transfection. Blots were probed with $\alpha$-STAT3, $\alpha$-cleaved caspase 3 and $\alpha$ - $\beta$-actin antibodies. C. AI 72 cells were transfected with STAT3 siRNA (bottom panel) or mock transfected with oligofectamine (top panel). After 96 hours, cells were isolated and immunostained with EGFP coupled anti-annexin $\mathrm{V}$ antibody. Cells were sorted by FACS and annexin V positive cells counted. The region shaded in black (77\%) corresponds the increase in annexin $\vee$ positive cells relative to the mock transfected cells.

results previously observed with dominant negative STAT3 in U251 cells [41]. Although STAT3 siRNA decreased the amount of STAT3 present in NHA, it did not have a significant effect on their viability. This suggests that STAT3 may be an ideal target for cancer therapy since inhibition of STAT3 signaling induces tumor cell death, but does not kill normal astrocytes.

One mechanism by which STAT3 participates in tumorigenesis is by inhibiting apoptosis through the induction of anti-apoptotic genes. Biochemical studies have shown that astrocytoma cells express a number of death receptors but are resistant to death receptor mediated apoptosis $[55,56]$. Other studies have shown that survivin is overexpressed in some tumors and that overexpression of the gene is sufficient to block apoptosis in tumor cells $[48,57,58]$. We have found that both Bcl-xL, a member of the BCL2 family of proteins, and survivin are expressed in A172 cells (Figure 5a \&5b). Treating A172 cells with STAT3 siRNA significantly reduces expression levels of both of these genes. STAT3 responsive elements are found in the promoter region of both of these genes, suggesting 


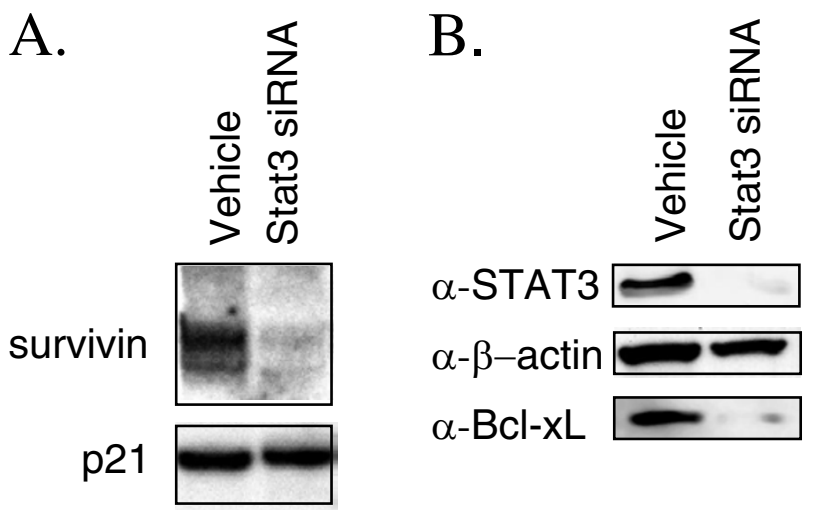

Figure 5

STAT3 controls expression of survivin and Bcl-xL in the AI 72 human glioblastoma cell line. A. AI72 cells were transfected with STAT3 siRNA or mock transfected with oligofectamine. After 72 hours, RNA was isolated from the cells and then analyzed by northern blotting for survivin and p2I mRNA. B. Al72 cells were transfected with STAT3 siRNA or mock transfected with oligofectamine. After 72 hrs, STAT3. $\beta$-actin, and $\mathrm{Bcl}-\mathrm{xL}$ expression levels were analyzed by Western blotting.

that they are directly regulated by STAT3 $[32,46]$. Our findings that $\mathrm{Bcl}-\mathrm{xL}$ is regulated by STAT3 in astrocytoma cell lines is consistent with previous data [41]. We are the first to report that STAT3 also regulates survivin expression in astrocytoma. Taken together with our data that knockdown of STAT3 can induce apoptosis, these findings suggest that induction of $\mathrm{Bcl}-\mathrm{xL}$ and survivin genes by constitutively activated STAT3 promotes survival of astrocytoma cells.

Not all the astrocytoma cell lines examined responded equally to STAT3 knockdown. This suggests that some astrocytomas are not dependent on STAT3 for survival. Further work is needed to determine whether this STAT3 independence has evolved from STAT3 dependent cells or more likely is a result of the specific types of oncogenic mutations in these tumors.

Data presented in this paper are consistent with the growing body of evidence suggesting STAT3 may be an important therapeutic target in tumors including astrocytoma. We are the first to report that an siRNA can induce apoptosis of astrocytoma cells. siRNAs are short oligonucleotides of 21-23 nucleotides in length that can be used in vitro to produce sequence specific gene silencing of mammalian cells [59]. It has been shown that siRNAs can be used effectively in vivo to suppress gene expression in adult mice $[60,61]$. siRNAs can be directly introduced into the CNS to reduce endogenous gene expression [62]. These results suggest that siRNA may become a useful clinical tool in the future. Since STAT3 signaling is important for the survival of a number of human tumors, STAT3 siRNA could become an effective therapeutic agent for STAT3 dependent tumors.

\section{Conclusions}

Knockdown of STAT3 expression by RNAi results in a reduction in expression of $\mathrm{Bcl}-\mathrm{xL}$ and survivin in A172 cells and leads to induction of apoptosis in this and other astrocytoma cell lines.

\section{Competing interests}

None declared.

\section{Authors' contributions}

BHC and LK conceived and designed the experiments and wrote the manuscript. LK performed most of the experiments. MK performed and interpreted the FACS analysis. MMK helped with siRNA experiments, northern blots, and tissue culture. All authors read and approved the final manuscript.

\section{Acknowledgements}

This work was supported by $\mathrm{NIH}$ grant GM5I55I to BHC. LK was supported by Medical Scientist training grant NIH T32 GM08448.

\section{References}

I. Maher EA, Furnari FB, Bachoo RM, Rowitch DH, Louis DN, Cavenee WK and DePinho RA: Malignant glioma: genetics and biology of a grave matter. Genes Dev 200I, I5:13 II-I333.

2. Rasheed BK, Wiltshire RN, Bigner SH and Bigner DD: Molecular pathogenesis of malignant gliomas. Curr Opin Oncol 1999, II:162-167.

3. Prados MD and Levin V: Biology and treatment of malignant glioma. Semin Oncol 2000, 27: I-10.

4. Holland EC: Glioblastoma multiforme: the terminator. Proc Natl Acad Sci U S A 2000, 97:6242-6244.

5. Wechsler-Reya R and Scott MP: The developmental biology of brain tumors. Annu Rev Neurosci 200I, 24:385-428.

6. Levin V A S. Leivei, P. H. Gutin: Neoplasms of the central nervous system In Cancer: Principles and practice of oncology. Edited by: V T DeVita S J Hellman SA Rosemberg. Philadelphia, LippincottRaven; 1997:2022-2082.

7. Libermann TA, Nusbaum HR, Razon N, Kris R, Lax I, Soreq H, Whittle N, Waterfield MD, Ullrich A and Schlessinger J: Amplification, enhanced expression and possible rearrangement of EGF receptor gene in primary human brain tumours of glial origin. Nature 1985, 3 I 3: |44- | 47.

8. Li J, Yen C, Liaw D, Podsypanina K, Bose S, Wang SI, Puc J, Miliaresis C, Rodgers L, McCombie R, Bigner SH, Giovanella BC, Ittmann M, Tycko B, Hibshoosh H, Wigler MH and Parsons R: PTEN, a putative protein tyrosine phosphatase gene mutated in human brain, breast, and prostate cancer. Science 1997, 275: 1943-1947.

9. Steck PA, Pershouse MA, Jasser SA, Yung WK, Lin H, Ligon AH, Langford LA, Baumgard ML, Hattier T, Davis T, Frye C, Hu R, Swedlund $B$, Teng $\mathrm{DH}$ and Tavtigian SV: Identification of a candidate tumour suppressor gene, MMACI, at chromosome I0q23.3 that is mutated in multiple advanced cancers. Nat Genet 1997 , 15:356-362. 
10. Ivanchuk SM, Mondal S, Dirks PB and Rutka JT: The INK4A/ARF locus: role in cell cycle control and apoptosis and implications for glioma growth. J Neurooncol 200I, 5 I:219-229.

1I. Ichimura K, Bolin MB, Goike HM, Schmidt EE, Moshref A and Collins VP: Deregulation of the $\mathrm{p}$ I4ARF/MDM2/p53 pathway is a prerequisite for human astrocytic gliomas with GI-S transition control gene abnormalities. Cancer Res 2000, 60:417-424.

12. Reifenberger G, Ichimura K, Reifenberger J, Elkahloun AG, Meltzer PS and Collins VP: Refined mapping of $12 q|3-q| 5$ amplicons in human malignant gliomas suggests CDK4/SAS and MDM2 as independent amplification targets. Cancer Res 1996, 56:5|4|-5|45

13. Schmidt EE, Ichimura K, Reifenberger G and Collins VP: CDKN2 (p I6/MTSI) gene deletion or CDK4 amplification occurs in the majority of glioblastomas. Cancer Res 1994, 54:632I-6324.

14. Ihle JN: STATs: Signal transducers and activators of transcription (review). Cell 1996, 84:33I-334.

15. Shuai K, Schindler C, Prezioso VR and Darnell J. E., Jr.: Activation of transcription by IFN-gamma: tyrosine phosphorylation of a 9I-kD DNA binding protein. Science 1992, 258:1808-1812

16. Schindler C, Shuai K, Prezioso VR and Darnell J. E., Jr.: Interferondependent tyrosine phosphorylation of a latent cytoplasmic transcription factor. Science 1992, 257:809-8/3.

17. Shuai K, Stark GR, Kerr IM and Darnell J. E., Jr.: A single phosphotyrosine residue of Stat9 I required for gene activation by interferon-gamma. Science 1993, 26 I: 1744-1746.

18. Shuai K, Horvath CM, Huang LH, Qureshi SA, Cowburn D and Darnell J. E., Jr.: Interferon activation of the transcription factor Stat9 I involves dimerization through SH2-phosphotyrosyl peptide interactions. Cell 1994, 76:82I-828.

19. Hayes TE, Kitchen AM and Cochran BH: Inducible binding of a factor to the c-fos regulatory region. Proc Natl Acad Sci U S A 1987, 84: $1272-1276$

20. Schindler C, Fu XY, Improta T, Aebersold R and Darnell J. E., Jr.: Proteins of transcription factor ISGF-3: one gene encodes the $9 \mathrm{I}$-and $84-\mathrm{kDa}$ ISGF-3 proteins that are activated by interferon alpha. Proc Natl Acad Sci U S A 1992, 89:7836-7839.

21. Wagner BJ, Hayes TE, Hoban CJ and Cochran BH: The SIF binding element confers sis/PDGF inducibility onto the c-fos promoter. Embo J 1990, 9:4477-4484.

22. Veals SA, Schindler C, Leonard D, Fu XY, Aebersold R, Darnell J. E., Jr. and Levy DE: Subunit of an alpha-interferon-responsive transcription factor is related to interferon regulatory factor and Myb families of DNA-binding proteins. Mol Cell Biol 1992, 1 2:3315-3324.

23. Stocklin E, Wissler M, Gouilleux F and Groner B: Functional interactions between Stat5 and the glucocorticoid receptor. Nature 1996, 383:726-728.

24. Ehret GB, Reichenbach P, Schindler U, Horvath CM, Fritz S, Nabholz $M$ and Bucher P: DNA binding specificity of different STAT proteins. Comparison of in vitro specificity with natural target sites. J Biol Chem 200I, 276:6675-6688.

25. Takeda $K$ and Akira S: STAT family of transcription factors in cytokine-mediated biological responses. Cytokine Growth Factor Rev 2000, II:199-207.

26. Hirano $T$, Ishihara $\mathrm{K}$ and Hibi M: Roles of STAT3 in mediating the cell growth, differentiation and survival signals relayed through the IL-6 family of cytokine receptors. Oncogene 2000, 19:2548-2556

27. Heinrich PC, Behrmann I, Muller-Newen G, Schaper F and Graeve L: Interleukin-6-type cytokine signalling through the gp I30/Jak/ STAT pathway. Biochem J 1998, 334 ( Pt 2):297-3।4.

28. Matsuda T, Nakamura $T$, Nakao $K$, Arai T, Katsuki M, Heike $T$ and Yokota T: STAT3 activation is sufficient to maintain an undifferentiated state of mouse embryonic stem cells. Embo J 1999 , I 8:4261-4269

29. Bromberg J: Stat proteins and oncogenesis. / Clin Invest 2002 109: $1139-1142$

30. Zhong Z, Wen Z and Darnell J. E., Jr.: Stat3: a STAT family member activated by tyrosine phosphorylation in response to epidermal growth factor and interleukin-6. Science 1994, 264:95-98

31. Rajan P and McKay RD: Multiple routes to astrocytic differentiation in the CNS. J Neurosci 1998, 18:3620-3629.

32. Catlett-Falcone R, Landowski TH, Oshiro MM, Turkson J, Levitzki A Savino R, Ciliberto G, Moscinski L, Fernandez-Luna JL, Nunez G, Dal- ton WS and Jove R: Constitutive activation of Stat3 signaling confers resistance to apoptosis in human U266 myeloma cells. Immunity 1999, 10:105-II5.

33. Bowman T, Garcia R, Turkson J and Jove R: STATs in oncogenesis. Oncogene 2000, 19:2474-2488.

34. Grandis JR, Drenning SD, Zeng Q, Watkins SC, Melhem MF, Endo S, Johnson DE, Huang L, He Y and Kim JD: Constitutive activation of Stat3 signaling abrogates apoptosis in squamous cell carcinogenesis in vivo. Proc Natl Acad Sci U S A 2000, 97:4227-4232.

35. Schuringa JJ, Wierenga AT, Kruijer W and Vellenga E: Constitutive Stat3, Tyr705, and Ser727 phosphorylation in acute myeloid leukemia cells caused by the autocrine secretion of interleukin-6. Blood 2000, 95:3765-3770.

36. Badache $A$ and Hynes NE: Interleukin 6 inhibits proliferation and, in cooperation with an epidermal growth factor receptor autocrine loop, increases migration of T47D breast cancer cells. Cancer Res 200I, 61:383-391.

37. Buettner R, Mora LB and Jove R: Activated STAT signaling in human tumors provides novel molecular targets for therapeutic intervention. Clin Cancer Res 2002, 8:945-954.

38. Turkson J, Bowman T, Garcia R, Caldenhoven E, De Groot RP and Jove R: Stat3 activation by Src induces specific gene regulation and is required for cell transformation. Mol Cell Biol 1998, 18:2545-2552.

39. Bromberg JF, Horvath CM, Besser D, Lathem WW and Darnell J. E., Jr.: Stat3 activation is required for cellular transformation by v-src. Mol Cell Biol 1998, I 8:2553-2558.

40. Mora LB, Buettner R, Seigne J, Diaz J, Ahmad N, Garcia R, Bowman T, Falcone R, Fairclough R, Cantor A, Muro-Cacho C, Livingston S, Karras J, Pow-Sang J and Jove R: Constitutive activation of Stat3 in human prostate tumors and cell lines: direct inhibition of Stat3 signaling induces apoptosis of prostate cancer cells. Cancer Res 2002, 62:6659-6666.

4I. Rahaman SO, Harbor PC, Chernova O, Barnett GH, Vogelbaum MA and Haque SJ: Inhibition of constitutively active Stat3 suppresses proliferation and induces apoptosis in glioblastoma multiforme cells. Oncogene 2002, $21: 8404-8413$.

42. Elbashir SM Harborth J, Lendeckel W, Yalcin A, Weber K, Tuschl T: Duplex of $2 \mathrm{I}$-nucleotide RNAs mediate RNA interfeerence in cultured mammalian cells. Nature 200 I, 4I I:494-498.

43. Elstein $\mathrm{KH}$ and Zucker RM: Comparison of cellular and nuclear flow cytometric techniques for discriminating apoptotic subpopulations. Exp Cell Res 1994, 21 I:322-331.

44. Chan A, Reiter R, Wiese S, Fertig G and Gold R: Plasma membrane phospholipid asymmetry precedes DNA fragmentation in different apoptotic cell models. Histochem Cell Biol 1998 , I 1 0:553-558.

45. Zushi S, Shinomura Y, Kiyohara T, Miyazaki Y, Kondo S, Sugimachi M, Higashimoto $Y$, Kanayama $S$ and Matsuzawa Y: STAT3 mediates the survival signal in oncogenic ras-transfected intestinal epithelial cells. Int J Cancer 1998, 78:326-330.

46. Aoki Y, Feldman GM and Tosato G: Inhibition of STAT3 signaling induces apoptosis and decreases survivin expression in primary effusion lymphoma. Blood 2003, I 0 I: I535-1542.

47. Martin S, Toquet C, Oliver L, Cartron PF, Perrin P, Meflah K, Cuillere $\mathrm{P}$ and Vallette FM: Expression of bcl-2, bax and bcl-xl in human gliomas: a re-appraisal. J Neurooncol 200I, 52: 129-I39.

48. Kleinschmidt-DeMasters BK, Heinz D, McCarthy PJ, Bobak JB, Lillehei $\mathrm{KO}$, Shroyer AL and Shroyer KR: Survivin in glioblastomas. Protein and messenger RNA expression and comparison with telomerase levels. Arch Pathol Lab Med 2003, I 27:826-833.

49. Li W, Liang X, Kellendonk C, Poli V and Taub R: STAT3 contributes to the mitogenic response of hepatocytes during liver regeneration. / Biol Chem 2002, 277:284 I I-284I7.

50. Niu G, Heller R, Catlett-Falcone R, Coppola D, Jaroszeski M, Dalton $W$, Jove $\mathrm{R}$ and $\mathrm{Yu} \mathrm{H}$ : Gene therapy with dominant-negative Stat3 suppresses growth of the murine melanoma B 16 tumor in vivo. Cancer Res 1999, 59:5059-5063.

51. Bromberg JF, Wrzeszczynska MH, Devgan G, Zhao Y, Pestell RG, Albanese $C$ and Darnell J. E., Jr.: Stat3 as an oncogene. Cell 1999. 98:295-303.

52. Cattaneo E, Magrassi L, De-Fraja C, Conti L, Di Gennaro I, Butti G and Govoni S: Variations in the levels of the JAK/STAT and ShcA proteins in human brain tumors. Anticancer Res 1998, 18:2381-2387. 
53. Thomas CY, Chouinard M, Cox M, Parsons S, Stallings-Mann M, Garcia $R$, Jove $R$ and Wharen $R$ : Spontaneous activation and signaling by overexpressed epidermal growth factor receptors in glioblastoma cells. Int J Cancer 2003, 104:19-27.

54. Tchirkov A, Rolhion C, Bertrand S, Dore JF, Dubost JJ and Verrelle P: IL-6 gene amplification and expression in human glioblastomas. Br J Cancer 200I, 85:5 I8-522.

55. Riffkin CD, Gray AZ, Hawkins CJ, Chow CW and Ashley DM: Ex vivo pediatric brain tumors express Fas (CD95) and FasL (CD95L) and are resistant to apoptosis induction. Neuro-oncol 200I, 3:229-240

56. Rieger J, Ohgaki $\mathrm{H}$, Kleihues $\mathrm{P}$ and Weller M: Human astrocytic brain tumors express AP02L/TRAIL. Acta Neuropathol (Berl) 1999, 97:1-4.

57. Das A, Tan WL, Teo J and Smith DR: Expression of survivin in primary glioblastomas. J Cancer Res Clin Oncol 2002, 1 28:302-306.

58. O'Driscoll L, Linehan R and Clynes M: Survivin: role in normal cells and in pathological conditions. Curr Cancer Drug Targets 2003, 3:131-152.

59. Elbashir SM, Harborth J, Lendeckel W, Yalcin A, Weber K and Tuschl T: Duplexes of 21 -nucleotide RNAs mediate RNA interference in cultured mammalian cells. Nature 200I, 4I I:494-498.

60. Lewis DL, Hagstrom JE, Loomis AG, Wolff JA and Herweijer H: Efficient delivery of siRNA for inhibition of gene expression in postnatal mice. Nat Genet 2002, 32:107-108.

61. McCaffrey AP, Meuse L, Pham TT, Conklin DS, Hannon GJ and Kay MA: RNA interference in adult mice. Nature 2002, 41 8:38-39.

62. Makimura H, Mizuno TM, Mastaitis JW, Agami R and Mobbs CV: Reducing hypothalamic AGRP by RNA interference increases metabolic rate and decreases body weight without influencing food intake. BMC Neurosci 2002, 3:18.

\section{Pre-publication history}

The pre-publication history for this paper can be accessed here:

http://www.biomedcentral.com/1471-2407/3/23/prepub

Publish with Biomed Central and every scientist can read your work free of charge

"BioMed Central will be the most significant development for disseminating the results of biomedical research in our lifetime. "

Sir Paul Nurse, Cancer Research UK

Your research papers will be:

- available free of charge to the entire biomedical community

- peer reviewed and published immediately upon acceptance

- cited in PubMed and archived on PubMed Central

- yours - you keep the copyright

Submit your manuscript here:

http://www.biomedcentral.com/info/publishing_adv.asp
BiolMedcentral 